\title{
Звезды аналитического приборостроения Рассел и Сигурд Варианы
}

\author{
Ю. А. Золотов, академик РАН ${ }^{1}$
}

\begin{abstract}
Мы продолжаем публикацию серии материалов о создателях крупнейших фирм, разрабатывающих и выпускающих аналитическое оборудование. В основу предлагаемых заметок положен перевод информационного бюллетеня, который в свое время подготовил и распространил на одной из Питтсбургских конференций по аналитической химии и прикладной спектроскопии (Pittcon) Американский Фонд химического наследия (Chemical Heritage Foundation)*.
\end{abstract}

Родившийся в Вашингтоне (округ Колумбия) в семье бедных ирландских эмигрантов, Рассел Харрисон Вариан (1898-1959) вместе с родными перебрался в 1914 году в Келкьён в Калифорнии. Он собирался изучать общественные науки в Стэнфордском университете, но уровень его подготовки не соответствовал предъявляемым требованиям. В результате он решил заниматься физикой. Однако из-за недостаточной подготовки по математике ему пришлось потратить шесть лет для получения степени бакалавра в 1925 году. Позднее в том же году Р. Вариан вернулся в Стэнфорд и поступил в магистратуру. Сначала он намеревался определить комптоновский сдвиг меди, но французский физик Луи де Бройль уже сделал это для железа и цинка, в результате Рассел решил измерить относительную интенсивность пиков комптоновского рассеяния, для чего сконструировал газонаполненную рентгеновскую трубку.

В 1927 году Рассел Вариан получил магистерскую степень, проработал после этого пять месяцев на фирме Humble Oil, получив патент на колебательный магнетометр. Далее он вполне успешно сотрудничал с Philo T. Farnsworth and Company, где занимался в том числе созданием ранних телевизионных систем. Продолжить научную деятельность в Стэнфордском университете не удалось заявка на получение докторской степени (PhD) была

\footnotetext{
Московский государственный университет им. М. В. Ломоносова. Статья из кн. Ю.А. Золотова "Очерки истории аналитической химии" (М.: ТЕХНОСФЕРА, 2018) публикуется с некоторыми изменениями.
}

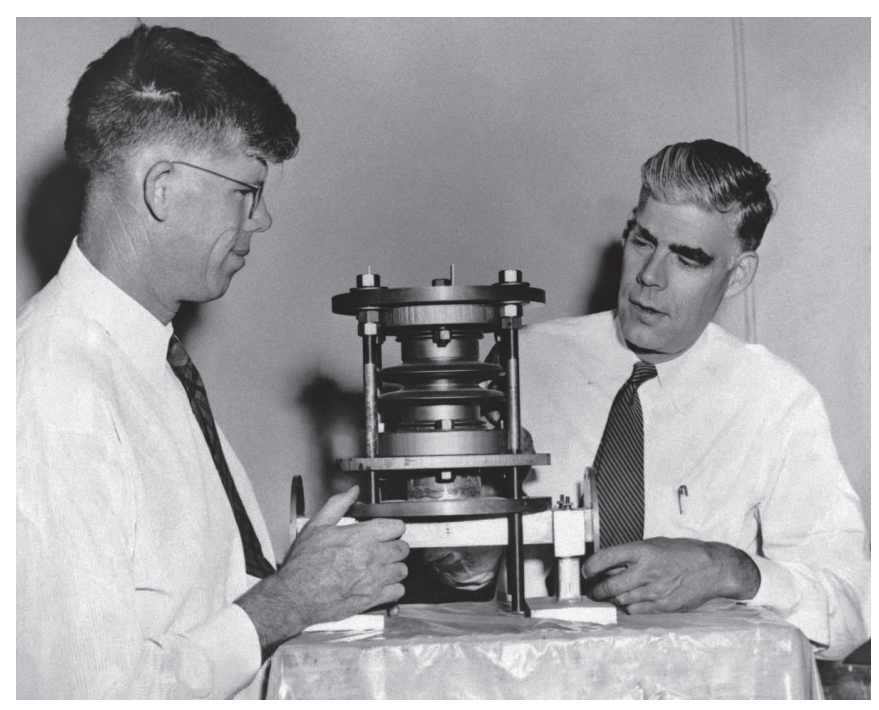

Рассел и Сигурд Варианы

отклонена из-за недостаточного опыта в области математики.

Младший брат Рассела Сигурд Фергус (1901-1961) с детства интересовался электротехникой и после школы поступил в Политехнический университет штата Калифорния, который так и не закончил: академическое образование ему показалось слишком скучным. Заинтересовавшись летным делом, он прошел обучение по пилотированию. Сначала выполнял частные заказы, а затем был принят в штат Pan American Airways. Это было время, когда компания разрабатывала новые маршруты в Латинскую Америку. Сигурд был одним из пилотов Pan Am, отобранных для первых полетов в Мексике и Центральной Америке. Во время работы в качестве 
капитана авиакомпании он жил в Мексике с 1929 по 1934 год. Работая с навигационными картами, он обнаружил в них много неточностей и ошибок. Сигурд убедился на своем опыте, как трудно безопасно приземлиться или обнаружить другие самолеты в ночное время или в пасмурную погоду. Он хорошо знал несовершенство навигационного оборудования и заинтересовался способами, как сделать полеты безопаснее. Большую часть жизни его преследовали проблемы со здоровьем - из-за обострившегося туберкулеза он вышел в отставку в середине 30-х годов 20 века.

В 1936 году братья объединили усилия в решении проблемы обнаружения самолетов высокочастотными радиосигналами. Идея состояла в разработке способной направлять поток электронов трубки, которая могла бы быть использована для различных приложений. Благодаря помощи приятеля Рассела по колледжу У. Хансена (W. Hansen), который к тому времени стал профессором, Стэнфордский университет предоставил братьям лабораторию и материалы на 100 долл. До лета 1937 года первая трубка-клистрон, как ее назвали, была сконструирована и в 1939 году формально представлена в Journal of Physics.

Британские ученые, не теряя времени, адаптировали клистроновую технологию для использования в радарных системах, которые помогли отразить налеты люфтваффе летом 1940 года. Дальнейшая исследовательская работа над клистроновой трубкой была поддержана компанией Sperry Gyroscope, и братья Вариан вместе со стэнфордским студентом Эдвардом Гинзтоном (E. Ginzton) обосновались в лаборатории этой компании в Лонг-Айленде (штат Нью-Йорк).

После войны клистрон стал важнейшим компонентом в дальнейшем развитии технологии радаров и микроволной индустрии. Рассел и Сигурд основали Varian Associates в 1948 году вместе с У. Хансеном и Э. Гинзтоном. Рассел стал президентом компании, а Сигурд - вице-президентом. Первоначально они создали компанию для коммерциализации клистрона и разработки других технологий, таких как небольшие линейные ускорители для генерации фотонов для лучевой терапии с использованием внешнего луча. В 1950 году Варианы были удостоены медалью John Price Wetherill института Франклина в знак признания их дальновидности, энергии и технической проницательности в разработке клистрона.

Varian Associates разработала ряд важных новинок, включая прибор ядерного магнитного резонанса (ЯМР) и линейный ускоритель для медицины. Рассел получил патенты на технологии, связанные с ядерным магнитным резонансом, которые используются в магнитно-резонансной томографии, термоэлектронных трубках и различных радиолокационных технологиях. Изобретения Сигурда включали систему насосов, фильтров и нагревателей для бассейна, высокоскоростной сверлильный станок и др. Сигурд также руководил проектами по созданию моделей и прототипов для превращения концепций Рассела в пригодные для использования продукты.

В 1950-х годах во время холодной войны компания выполняла военные заказы, один из которых взрыватель для атомной бомбы. Впоследствии братья выразили сожаление о том, что приняли участие в разработке оружия массового уничтожения.

Штаб-квартира компании первоначально располагалась в Сан-Карлос (Калифорния), а затем переместилась Пало-Альто (Калифорния) в Стэнфордский индустриальный парк и стала одной из первых высокотехнологичных компаний Кремниевой долины.

Мечта Рассела получить докторскую степень осуществилась - он был удостоен почетной степени доктора технических наук Политехнического института Бруклина. Политехнический колледж штата Калифорния назвал его выпускником года за изобретение клистрона.

В 1993 году братья Вариан были посмертно занесены в Зал славы Совета инженеров Кремниевой долины.

В 1998 году Varian Associates отмечала 50-летие со дня основания и была названа драгоценным камнем в короне Кремниевой долины.

В начале 21 века была учреждена премия Рассела Вариана - международная научная награда, присуждаемая за единичный, значительный и инновационный вклад в области ядерного магнитного резонанса в память пионера в создании коммерческого яМР-спектрометра и соучредителя одной из первых высокотехнологичных компаний в Кремниевой долине. Премия 15 тыс. евро вручалась ежегодно в период с 2002 по 2015 год (кроме 2003 года) комитетом экспертов в области ЯМР. Церемонию награждения поочередно проводили на Европейской конференции по магнитному резонансу (EUROMAR) и конференции Международного совета по магнитному резонансу в биологических системах (ICMRBS). Первоначально премию спонсировала Varian, Inc., а затем Agilent Technologies, которая приобрела Varian, Inc. в 2010 году. С 2016 года премия прекратила существование после того, как Agilent Technologies закрыла свое подразделение ЯМР. 